\title{
A proteomic profiling of gemcitabine resistance in pancreatic cancer cell lines
}

\author{
SAYAKA MORI-IWAMOTO ${ }^{1,2}$, YASUHIRO KURAMITSU ${ }^{2}$, SHOMEI RYOZAWA ${ }^{1}$, KUMIKO TABA ${ }^{1}$, \\ MASANORI FUJIMOTO ${ }^{2}$, KIWAMU OKITA ${ }^{3}$, KAZUYUKI NAKAMURA ${ }^{2}$ and ISAO SAKAIDA $^{1}$ \\ ${ }^{1}$ Department of Gastroenterology and Hepatology, and ${ }^{2}$ Department of Biochemistry and Functional Proteomics, \\ Yamaguchi University Graduate School of Medicine, 1-1-1 Minamikogushi, Ube, Yamaguchi 755-8505; \\ ${ }^{3}$ Shimonoseki Kosei Hospital, 3-3-8 Kamishinchi, Shimonoseki, Yamaguchi 750-0061, Japan
}

Received December 20, 2007; Accepted February 25, 2008

\begin{abstract}
Pancreatic cancer is one of the most highly fatal cancers and is generally resistant to chemotherapy. Currently, gemcitabine appears to be the only effective agent for its treatment and is the preferred first-line therapy. However, the clinical impact of gemcitabine remains modest due to a high level of inherent and acquired tumor resistance. We investigated protein expression in gemcitabine-resistant and -sensitive human pancreatic adenocarcinoma cell lines by proteomics. Tumor cell proteins were separated by two-dimensional gel electrophoresis, then the protein spots that showed increased or decreased expression in gemcitabine-sensitive cell lines were identified by liquid chromatography-tandem mass spectrometry (LC-MS/MS) and Western blotting. Nine out of ten proteins showing differential expression in gemcitabine-resistant and -sensitive cell lines were identified, confirming an increase in heat shock protein 27 (HSP27) and a decrease in nucleophosmin (NPM) in the resistant lines. These results suggest that HSP27 and NPM may play a role in the poor response of pancreatic cancer to gemcitabine.
\end{abstract}

\section{Introduction}

Pancreatic cancer is characterized by its difficulty of diagnosis, aggressiveness and lack of effective nonsurgical therapy, so that only $1-4 \%$ of patients with adenocarcinoma of the pancreas survive for more than 5 years after diagnosis $(1,2)$. Surgical resection is the only curative treatment currently available, but only $10-15 \%$ of patients have no metastases at the time of tumor detection. Gemcitabine (2'-deoxy-2'-difluorodeoxycytidine, Gemzar) is a deoxycytidine analogue with structural and metabolic similarities to cytarabine. Currently, this nucle-

Correspondence to: Dr Yasuhiro Kuramitsu, Department of Biochemistry and Functional Proteomics, Yamaguchi University Graduate School of Medicine, 1-1-1 Minamikogushi, Ube, Yamaguchi 755-8505, Japan

E-mail: climates@yamaguchi-u.ac.jp

Key words: pancreatic cancer, proteomics, gemcitabine, drug resistant, heat shock protein 27 , nucleophosmin oside analogue appears to be the only drug to exhibit activity against pancreatic cancer (3). However, the median survival time of patients treated with gemcitabine is only 6.3 months (range 1.6-19.2) (4). Intrinsic or acquired resistance to apoptosis is an important factor in the failure of this agent to control pancreatic cancer $(5,6)$. Better understanding of the cellular and molecular mechanisms involved in gemcitabine resistance is necessary for this drug to be used more effectively; indeed, some reports concerning the mechanism of its resistance have already been published.

Overexpression of mdr-1, the gene which encodes $\mathrm{P}$-glycoprotein $(\mathrm{P}-\mathrm{gP})$, has been shown to induce resistance to various anticancer drugs (7-9). However, it has been reported that gemcitabine resistance is not mediated by P-gP (10), and that $\mathrm{P}$-gP-overexpressing cells are actually more sensitive to gemcitabine than parental cells (11). Other studies have indicated that the loss of BNIP3 expression is a late event that contributes to the chemoresistance of pancreatic cancer (12), that equilibrative-sensitive nucleoside transporter plays an important role in gemcitabine sensitivity (13) while the overexpression of carcinoembryonic antigen-related cell adhesion molecule 6 can protect pancreatic adenocarcinoma cells against gemcitabine-induced cytotoxicity (14), that Selenoprotein $\mathrm{P}$ reduces the intracellular level of reactive oxygen species, resulting in the loss of sensitivity to gemcitabine (15), and that an increase in Src tyrosine kinase activity represents a potential mechanism of chemoresistance (16). However, the results of these studies are controversial.

Proteomic analysis is a powerful tool for the identification of overall differences in protein expression between drug-resistant and -sensitive cells. The aim of this study was to identify proteins showing differential expression in gemcitabine-resistant and -sensitive pancreatic cancer cell lines by using proteomics. Such proteins may potentially play a role in the chemoresistance of pancreatic cancer.

\section{Materials and methods}

Cell lines and culture. Three human pancreatic adenocarcinoma cell lines (MiaPaCa-2, BxPC-3 and AsPC-1) were purchased from the American Type Culture Collection. Panc-1, PK45p and PK59 were kindly provided by the Institute of Development, Aging and Cancer at Tohoku University. Panc-1 
Table I. The cytotoxicity of gemcitabine in the pancreatic cancer cell lines.

\begin{tabular}{|c|c|c|c|c|c|c|}
\hline & \multicolumn{6}{|c|}{ Cell lines } \\
\hline & $\mathrm{MiaPaCa}-2$ & Panc-1 & BxPC-3 & AsPC-1 & PK45p & PK59 \\
\hline $\mathrm{IC}_{50}(\mu \mathrm{g} / \mathrm{ml})$ & 6.81 & 8.07 & 6.67 & 1.05 & 417.45 & 294.72 \\
\hline
\end{tabular}

(a)

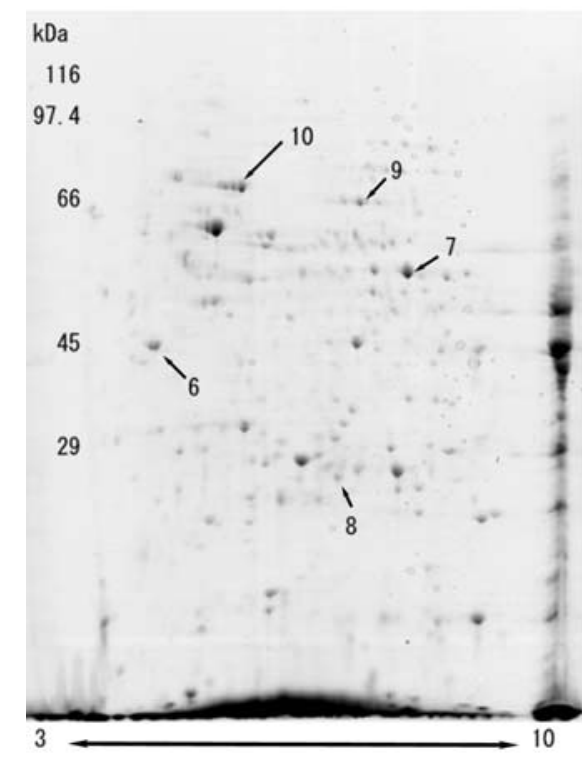

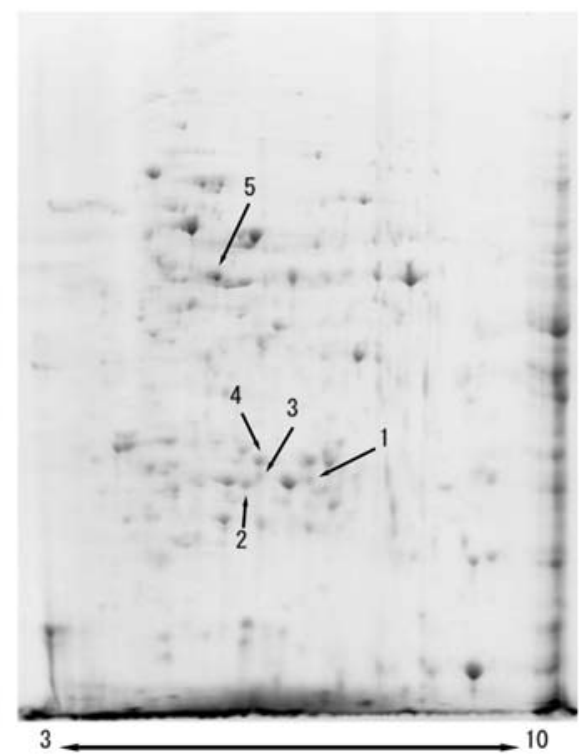

(b)

Figure 1. 2-DE gel pattern of (a) MiaPaCa-2 (gemcitabine-sensitive cell line) and (b) PK59 (gemcitabine-resistant cell line). Proteins (300 $\mu$ g) were separated on $12.5 \%$ non-gradient polyacrylamide gels and stained with CBB. Five spots (nos. 6-10) were more weakly expressed in gemcitabine-resistant than -sensitive cells. Five spots (nos. 1-5) had higher expression levels in gemcitabine-resistant than -sensitive cells.

and MiaPaCa-2 cells were grown in Dulbecco's modified Eagle's medium with $4 \mathrm{mM}$ L-glutamine adjusted to contain $1.5 \mathrm{~g} / \mathrm{l}$ sodium bicarbonate, $4.5 \mathrm{~g} / 1$ glucose and $10 \% \mathrm{FCS}$. BxPC-3, AsPC-1, PK45p and PK59 cells were grown in RPMI-1640 medium with $2 \mathrm{mM}$ L-glutamine adjusted to contain $1.5 \mathrm{~g} / \mathrm{l}$ sodium bicarbonate, $4.5 \mathrm{~g} / 1$ glucose, $10 \mathrm{mM}$ HEPES, $1.0 \mathrm{mM}$ sodium pyruvate and $10 \%$ FCS. Cells were incubated in a humidified atmosphere containing $5 \% \mathrm{CO}_{2}$ at $37^{\circ} \mathrm{C}$. Culturing was conducted without endotoxin.

Cell proliferation assay. Cells from each cell line (MiaPaCa-2, Panc-1, BxPC-3, AsPC-1, PK45p and PK59) were seeded into 96-well plates at a density of 1,000-5,000/well, incubated for $24 \mathrm{~h}$ and exposed to various concentrations of gemcitabine for $72 \mathrm{~h}$. Then, $10 \mu \mathrm{l}$ of 3-(4,5-dimethythiazol-2-yl)-2,5diphenyltetrazolium bromide (MTT assay) was added to each well, and further incubation was carried out for $4 \mathrm{~h}$. Next, the formazan crystal product was dissolved by adding $100 \mu 1$ of DMSO and incubating the plates for $1 \mathrm{~h}$ with protection from light to completely dissolve the crystals. Finally, the absorbance was measured at a wavelength of $570 \mathrm{~nm}$ with an ELISA plate reader (Model 550 Microplate Reader; Bio-Rad, Hercules, CA). It was confirmed that the absorbance showed a linear relationship with the number of cells. The experiments were repeated three times.
Sample preparation. The suspensions of cultured cells were centrifuged at 1,500 rpm for $5 \mathrm{~min}$. Each pellet was then washed three times with $10 \mathrm{mM}$ PBS (-), pH 7.4, and was lysed in lysis buffer (1\% NP-40, $1 \mathrm{mM}$ sodium vanadate, $1 \mathrm{mM}$ PMSF, $50 \mathrm{mM}$ Tris, $10 \mathrm{mM} \mathrm{NaF}, 10 \mathrm{mM}$ EDTA, $165 \mathrm{mM} \mathrm{NaCl}, 10 \mu \mathrm{g} / \mathrm{ml}$ leupeptin and $10 \mu \mathrm{g} / \mathrm{ml}$ aprotinin) using a Potter homogenizer with a teflon coating at $4^{\circ} \mathrm{C}$ for $1 \mathrm{~h}$. The lysate was separated by centrifugation at $15,000 \mathrm{x} \mathrm{g}$ for $30 \mathrm{~min}$, and the supernatant was stored at $-80^{\circ} \mathrm{C}$. Protein samples for each cell line were obtained three times.

Two-dimensional gel electrophoresis. Protein (300 $\mu \mathrm{g})$ was used for each two-dimensional gel electrophoresis (2-DE) assay. First-dimension IEF was performed on 7-cm immobilized strips with a linear $\mathrm{pH}$ gradient of 3-10 (GE Healthcare Bio-Science Corp., Piscataway, NJ) at $20^{\circ} \mathrm{C}$ and $50 \mathrm{~mA}$. The strips were then rehydrated with $125 \mu 1$ of sample solution (8 $\mathrm{M}$ urea, 2\% CHAPS and $0.5 \%$ IPG buffer) for $14 \mathrm{~h}$. IEF was performed in three steps; $500 \mathrm{~V}$ for $1 \mathrm{~h}, 1,000 \mathrm{~V}$ for $1 \mathrm{~h}$ and $8,000 \mathrm{~V}$ for $2 \mathrm{~h}$. Voltage increases were carried out according to a gradient. The second-dimension was run on precast polyacrylamide gels (2-D homogeneous 12.5; GE Healthcare) in two steps; $600 \mathrm{~V}, 20 \mathrm{~mA}$ for $30 \mathrm{~min}$ and $600 \mathrm{~V}$, $50 \mathrm{~mA}$ for $70 \mathrm{~min}$. After electrophoresis, the gels were stained with CBB R-250 (Nacalai Tesque, Kyoto, Japan) for 
(a)

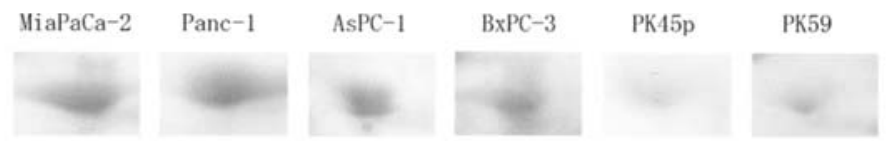

(b)

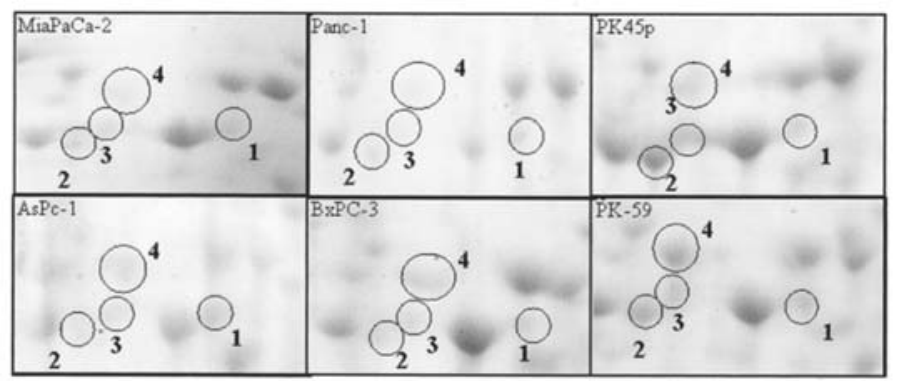

Figure 2. Comparison of spots in gemcitabine-sensitive cells (MiaPaCa-2, Panc-1, BxPC-3, AsPC-1) and gemcitabine-resistant cells (PK45p, PK59). The spot numbers correspond to those in Fig. 1. (a) Downregulated expression spots in gemcitabine-resistant cells. This protein was nucleophosmin. (b) Upregulated expression spots in gemcitabine-sensitive cells. Spots 1-3 were heat shock protein. Spot 4 was 6-phosphogluconolactonase.

24 h. Subsequently, they were de-stained with $10 \%$ acetic acid in water containing $30 \%$ methanol for $30 \mathrm{~min}$ and then stained with $7 \%$ acetic acid and used for in-gel digestion. Similar experiments for all cell lines were repeated in triplicate.

Image analysis. The positions of the protein spots on the gels obtained using samples of KLM1 and KLM1-R cells were recorded with an Agfa Arcus 1200 Image Scanner (AgfaGevaert N.V., Mortsel, Belgium) and were analyzed with Progenesis software (Progenesis PG240; Perkin-Elmer Inc., Wellesley, MA). Spots that were visible at different intensities were excised from the gels and stored in $100 \mu 1$ of ultrapure water at $80^{\circ} \mathrm{C}$ as samples for MS analysis.

In-gel digestion. After cutting the target protein spots from the gels, CBB dye was removed by rinsing three times in $60 \%$ methanol, $50 \mathrm{mM}$ ammonium bicarbonate and $5 \mathrm{mM}$ DTT for $15 \mathrm{~min}$, and twice in $50 \% \mathrm{CAN}, 50 \mathrm{mM}$ ammonium bicarbonate and $5 \mathrm{mM}$ DTT for $10 \mathrm{~min}$. The gel pieces were dehydrated in $100 \%$ acetonitrile (ACN) twice for 30 min each, and then rehydrated with an in-gel digestion reagent containing $10 \mu \mathrm{g} / \mathrm{ml}$ of sequencing grade modified trypsin (Promega, Madison, WI) in 30\% ACN, $50 \mathrm{mM}$ ammonium bicarbonate and $5 \mathrm{mM}$ DTT. In-gel digestion was performed overnight at $30^{\circ} \mathrm{C}$. The samples were rinsed in $30 \% \mathrm{ACN}, 50 \mathrm{mM}$ ammonium bicarbonate and $5 \mathrm{mM}$ DTT for $2 \mathrm{~h}$ and lyophilized overnight at $-30^{\circ} \mathrm{C}$.

Liquid chromatography-tandem mass spectrometry. Lyophilized samples were dissolved in $20 \mathrm{ml}$ of $0.1 \%$ formic acid and centrifuged at $15,000 \times \mathrm{g}$ for $5 \mathrm{~min}$. Sequencing of the identified protein spots was performed by liquid chromatography-tandem mass spectrometry (LC-MS/MS) with a Spectrum Mill MS Proteomics Workbench (Agilent Technologies, Santa Clara, CA, USA).

Western blot analysis. Samples $(30 \mu \mathrm{g})$ were separated by SDS-PAGE at $15 \mathrm{~mA}$, and then proteins on the gels were transferred electrophoretically to PVDF membranes (Immobilon-P; Millipore, Bedford, MA) that were blocked overnight at $4^{\circ} \mathrm{C}$ with TBS containing 5\% skim milk. Primary antibodies were anti-heat shock protein 27 (HSP27) monoclonal antibody
(1:600) and anti-B23 monoclonal antibody (Santa Cruz Biotechnology, Santa Cruz, CA). Membranes were incubated with the primary antibody for $1 \mathrm{~h}$ at room temperature, washed three times with TBS containing $0.05 \%$ Tween-20, washed once with TBS and then incubated for $1 \mathrm{~h}$ at room temperature with horseradish peroxidase-conjugated secondary antibody (1:2000) (ICN Pharmaceuticals, Aurora, OH). Final development was performed with a chemiluminescence reagent (ECL Western Blotting Detection Reagents; Amersham Pharmacia Biotechnology).

\section{Results}

Selection of pancreatic cancer cell lines by gemcitabine exposure. To evaluate the cytotoxicity of gemcitabine in the pancreatic cancer cell lines, MiaPaCa-2, Panc-1, AsPC-1, BxPC-3, PK45p and PK59 cells were exposed to different concentrations of the drug for $72 \mathrm{~h}$. Based on the measurements obtained, the $\mathrm{IC}_{50}$ value was defined as the concentration of gemcitabine causing 50\% inhibition of growth (Table I). Four cell lines, MiaPaCa-2, Panc-1, AsPC-1 and BxPC-3, showed a high sensitivity to gemcitabine with $\mathrm{IC}_{50}$ values of, respectively, 6.81, 8.07, 1.05 and $6.67 \mu \mathrm{g} / \mathrm{ml}$ (Table I). In contrast, PK45p and PK59 cells were much less sensitive. Their $\mathrm{IC}_{50}$ values were 417.45 and $294.72 \mu \mathrm{g} / \mathrm{ml}$, respectively (Table I). The cell lines were classified into two groups: gemcitabinesensitive cells (MiaPaCa-2, Panc-1, AsPC-1 and BxPC-3) and gemcitabine-resistant cells (PK45p and PK59).

Detection and identification of proteins in two-dimensional electrophoresis gels. Protein expression was assessed in three samples each from MiaPaCa-2, Panc-1, AsPC-1, BxPC-3, PK45p and PK59 cells cultured under the same conditions. More than 500 spots were visualized on the 2-DE gels, and differences in intensity between the gemcitabine-resistant and -sensitive cells were compared visually and analyzed with Image Master. Five of the spots showed a decrease in protein content in gemcitabine-resistant cell lines (nos. 6-10), while the other five showed an increase (nos. 1-5) (Fig. 1). The comparison between each spot is shown in Fig. 2. After the ten spots were cut out from each gel, analysis and identification were conducted by LC-MS/MS analysis. Information about the 
Table II. Identification of differentially-expressed proteins in gemcitabine-resistant and -sensitive cells.

\begin{tabular}{|c|c|c|c|c|c|c|}
\hline $\begin{array}{c}\text { Protein } \\
\text { no. }\end{array}$ & $\begin{array}{l}\text { Molecular } \\
\text { mass (Da) }\end{array}$ & $\mathrm{pI}$ & Protein identification & $\begin{array}{c}\text { Sensitive cells }{ }^{\mathrm{b}} \\
(\text { Rate average } \pm \mathrm{SD})\end{array}$ & $\begin{array}{c}\text { Resistant cells }^{\mathrm{b}} \\
(\text { Rate average } \pm \mathrm{SD})\end{array}$ & $\mathrm{p}$-value ${ }^{\mathrm{c}}$ \\
\hline \multirow[t]{2}{*}{1} & 22,782 & 5.98 & Heat shock protein 27 & $0.97 \pm 0.75$ & $1.41 \pm 0.87$ & 0.310 \\
\hline & 28,993 & 6.77 & ERp29 precursor & & & \\
\hline 2 & 22,787 & 5.98 & Heat shock protein 27 & $1.11 \pm 0.39$ & $4.51 \pm 3.68$ & 0.048 \\
\hline 3 & 22,787 & 5.98 & Heat shock protein 27 & $0.71 \pm 0.52$ & $2.25 \pm 1.97$ & 0.019 \\
\hline 4 & 27,547 & 5.70 & 6-phosphogluconolactonase & $0.51 \pm 0.48$ & $1.48 \pm 0.79$ & 0.001 \\
\hline 5 & 69,267 & 5.95 & Ezrin (p81)(cytovillin)(villin) & $0.81 \pm 0.37$ & $6.26 \pm 8.73$ & 0.460 \\
\hline 6 & 32,575 & 4.64 & Nucleophosmin & $0.93 \pm 0.41$ & $0.37 \pm 0.28$ & 0.008 \\
\hline 7 & 47,038 & 6.99 & $\alpha$ enolase & $1.97 \pm 1.41$ & $0.51 \pm 0.48$ & 0.027 \\
\hline 8 & 26,538 & 6.51 & Triosephosphate isomerase & $0.96 \pm 0.52$ & $0.74 \pm 0.78$ & 0.470 \\
\hline \multirow[t]{2}{*}{9} & 62,639 & 6.40 & Stress-induced-phosphoprotein 1 & $1.22 \pm 0.62$ & $0.73 \pm 0.42$ & 1.000 \\
\hline & 74,139 & 6.57 & Lamin A/C (70 kDa lamin) & & & \\
\hline 10 & - & - & Unidentified & - & - & - \\
\hline
\end{tabular}

${ }^{a}$ Spot numbers corresponding to those in Fig. $1 .{ }^{b}$ The percentage of spot intensity of each cell line to MiaPaCa-2. ${ }^{c}$ Differences in expression between gemcitabine-sensitive and -resistant cells analyzed by the Student's t-test.

(a)

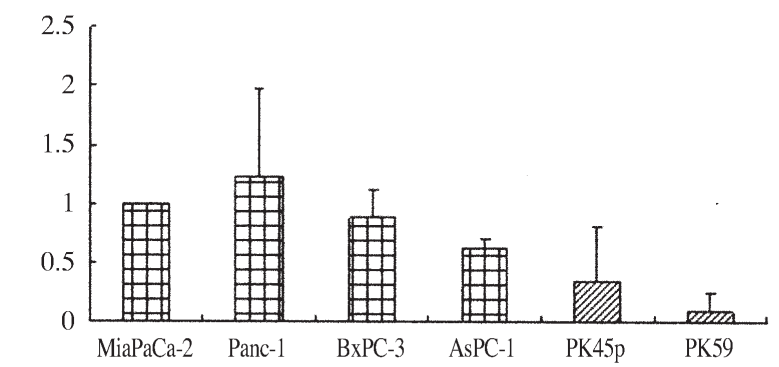

(c)

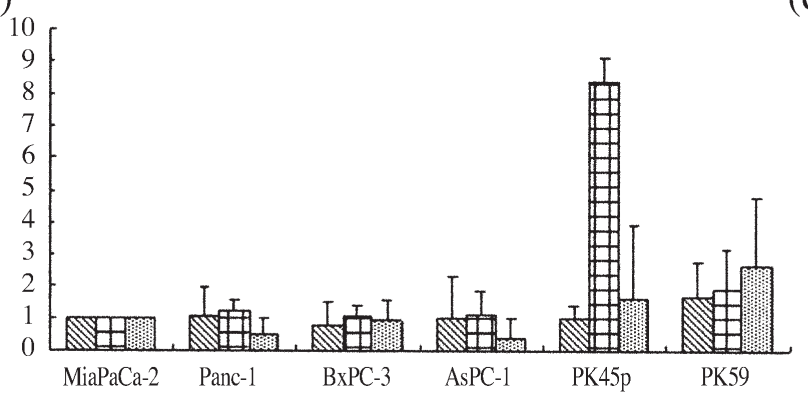

(b)

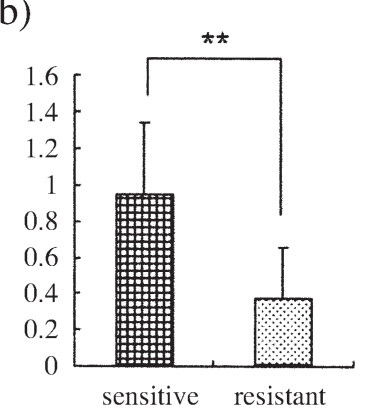

(d)

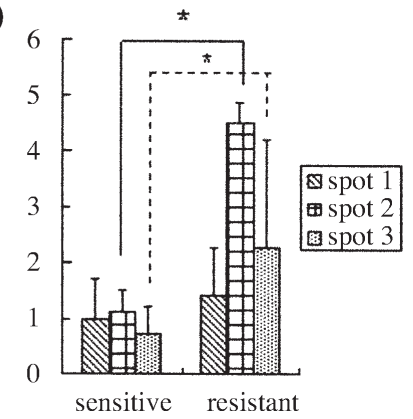

Figure 3. Expression analysis of nucleophosmin ( $\mathrm{a}$ and b) and HSP27 (c and d). Expression levels of proteins were quantified by analyzing the percentage of volume, the intensity and the area of each spot (MiaPaCa-2 was 1.00). The y-axis shows the percentage of volume; the $\mathrm{x}$-axis, each cell line. Differences in expression between sensitive and resistant cells were analyzed by the Student's t-test; ${ }^{*} \mathrm{p}<0.05,{ }^{* *} \mathrm{p}<0.01$. Data are expressed as the mean of each protein $\pm \mathrm{SD}$.

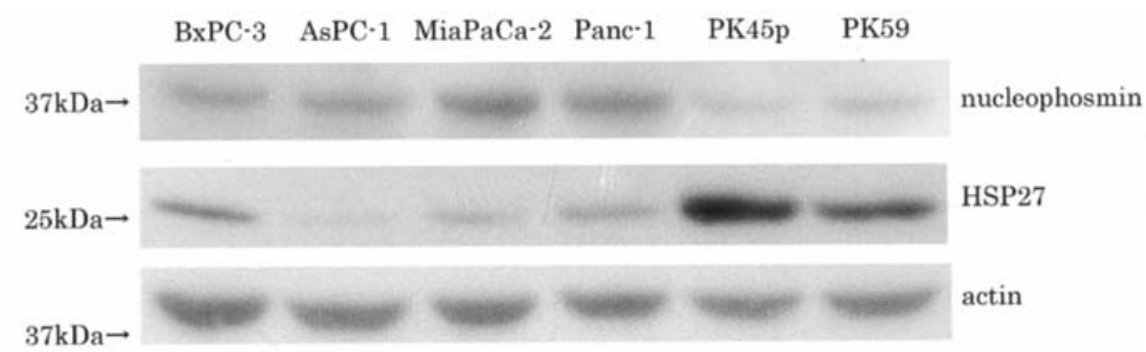

Figure 4. Immunoblot analysis of nucleophosmin and HSP27. Expression of nucleophosmin and HSP27 was confirmed. The intensity of the spot of nucleophosmin was weaker in gemcitabine-resistant cells, and the intensity of the spot of HSP27 was stronger. 
nine proteins thus identified is summarized in Table II. HSP27 and nucleophosmin (NPM) demonstrated a significant change in their ratios, as shown in Fig. 3 (Student's t-test, $\mathrm{p}<0.05$ ).

Western blot analysis of differentially-expressed proteins. The expression of two proteins (HSP27 and NPM) for which antibodies were available was confirmed by immunoblotting. HSP27 was upregulated and NPM downregulated in PK45p and PK59 (Fig. 4). The expression of ezrin, triosephosphate isomerase and $\alpha$-enolase was not confirmed by immunoblotting (data not shown).

\section{Discussion}

In the present study, proteomic analysis showed that HSP27 expression was increased and NPM expression decreased in gemcitabine-resistant cell lines.

HSP27 belongs to the family of small heat shock proteins, molecular chaperones that modulate the response of cells to injury and are found in virtually all organisms, from prokaryotes to mammals (17). A previous study demonstrated that HSP27 regulates apoptosis by interacting with key components of the apoptotic signaling pathway (18), and inhibits etoposideinduced apoptosis by preventing cytochrome c and dATPtriggered activation of caspase- 9 , which occurs downstream of cytochrome c release $(19,20)$. The increase of an anti-apoptotic factor such as HSP27 would enhance the ability of cells to resist chemotherapy. In fact, HSP27 overexpression inhibits the doxorubicin-induced apoptosis of human breast cancer cells (21), as well as inhibiting the etoposide-, diethylmaleate-, cycloheximide- or radiation-induced apoptosis of prostate cancer cells (22), and the etoposide-induced apoptosis of neuroblastoma cells (23). We did not examine expression with the regulation of HSP27, but it has been reported that when HSP27 is knocked down by siRNA 5-fluorouracil sensitivity in colon cancer is increased (24). As with these cancers, the present study revealed that HSP27 was also overexpressed by gemcitabine-resistant tumor cell lines, suggesting that pancreatic carcinoma may acquire gemcitabine resistance via the anti-apoptotic activity of HSP27. Accordingly, HSP27 might play an important role in tumor resistance to gemcitabine.

NPM is a multifunctional protein involved in several aspects of nucleolar function. This protein plays a role in the processing of pre-rRNA (25), and also acts as a histone chaperone (26). The expression of NPM is downregulated in cells undergoing differentiation or apoptosis (27). Berberineand retinoic acid-induced apoptosis of human leukemia cells is associated with the downregulation of NPM expression and telomerase activity $(28,29)$. In contrast, our study showed that NPM was decreased in gemcitabine-resistant cells. Gao et al reported that NPM regulates the nuclear translocation of GADD45a and contributes to GADD45a-induced cell cycle arrest in the G2-M phase (30), but that gemcitabine-induced apoptosis is not related to G2-M arrest. Thus, NPM may regulate the apoptosis of pancreatic adenocarcinoma cells by other mechanisms.

Apoptosis-regulating proteins from the bcl-2 family and $\mathrm{P}-\mathrm{gP}$ have been reported to participate in resistance to chemotherapy (5,31-33), but differences in the expression of these proteins in gemcitabine-sensitive and -resistant cells were not demonstrated in our study. Four proteins besides NPM were decreased and three proteins besides HSP27 were increased in the gemcitabine-resistant cell lines, suggesting that various proteins may participate in modulating gemcitabine sensitivity, in addition to NPM and HSP27. Therefore, further study of these proteins needs to be performed using surgical specimens, and blood levels of HSP27 should be examined in cancer patients as a possible marker for pancreatic cancer.

In conclusion, proteomic analysis was useful for the detection of intracellular proteins with differential expression in pancreatic adenocarcinoma cell lines sensitive or resistant to gemcitabine. Such proteins may be involved in the mechanism of resistance to chemotherapy, and could also be indicators of response to pancreatic cancer therapy.

\section{References}

1. Williamson RC: Pancreatic cancer: the greatest oncological challenge. Br Med J (Clin Res Ed) 13: 445-446, 1988.

2. Gordis L and Gold EB: Epidemiology of pancreatic cancer. World J Surg 8: 808-821, 1984.

3. Burris HA III, Moore MJ, Andersen J, et al: Improvements in survival and clinical benefit with gemcitabine as first-line therapy for patients with advanced pancreas cancer: a randomized trial. J Clin Oncol 15: 2403-2413, 1977.

4. Carmichael J, Fink U, Russell RC, Spittle MF, Harris AL, Spiessi G and Blatter J: Phase II study of gemcitabine in patients with advanced pancreatic cancer. Br J Cancer 73: 1-5, 1996.

5. Bold RJ, Chandra J and McConkey DJ: Gemcitabine-induced programmed cell death (apoptosis) of human pancreatic carcinoma is determined by Bcl-2 content. Ann Surg Oncol 6: 279-285, 1999.

6. Shi X, Liu S, Kleeff J, Friess $\mathrm{H}$ and Buchler MW: Acquired resistance of pancreatic cancer cells towards 5-fluorouracil and gemcitabine is associated with altered expression of apoptosisregulating genes. Oncology 62: 354-362, 2002.

7. Cantwell BM, Bozzino JM, Corris P and Harris AL: The multidrug resistant phenotype in clinical practice: evaluation of cross resistance to ifosfamide and mesna after VP16-213, doxorubicin and vincristine (VPAV) for small cell lung cancer. Eur J Cancer Clin Oncol 24: 123-129, 1988.

8. Licht T, Fiebig HH, Bross KJ, Herrmann F, Berger DP, Shoemaker R and Mertelsmann R: Induction of multiple-drug resistance during anti-neoplastic chemotherapy in vitro. Int $\mathrm{J}$ Cancer 49: 630-637, 1991.

9. Kato S, Nishimura J, Yufu Y, Ideguchi H, Umemura T and Nawata H: Modulation of expression of multidrug resistance gene (mdr-1) by adriamycin. FEBS Lett 308: 175-178, 1992.

10. Togawa A, Ito H, Kimura F, et al: Establishment of gemcitabineresistant human pancreatic cancer cells and effect of brefeldin-a on the resistant cell line. Pancreas 27: 220-224, 2003.

11. Bergman AM, Pinedo HM, Talianidis I, Veerman G, Loves WJ, van der Wilt CL and Peters GJ: Increased sensitivity to gemcitabine of P-glycoprotein and multidrug resistance-associated protein-overexpressing human cancer cell lines. Br J Cancer 88: 1963-1970, 2003.

12. Erkan M, Kleeff J, Esposito I, et al: Loss of BNIP3 expression is a late event in pancreatic cancer contributing to chemoresistance and worsened prognosis. Oncogene 24: 4421-4432, 2005.

13. Rauchwerger DR, Firby PS, Hedley DW and Moore MJ: Equilibrative-sensitive nucleoside transporter and its role in gemcitabine sensitivity. Cancer Res 60: 6075-6079, 2000.

14. Duxbury MS, Ito H, Benoit E, Waseem T, Ashley SW and Whang EE: A novel role for carcinoembryonic antigen-related cell adhesion molecule 6 as a determinant of gemcitabine chemoresistance in pancreatic adenocarcinoma cells. Cancer Res 64: 3987-3993, 2004

15. Maehara S, Tanaka S, Shimada M, Shirabe K, Saito Y, Takahashi K and Maehara Y: Selenoprotein P, as a predictor for evaluating gemcitabine resistance in human pancreatic cancer cells. Int J Cancer 112: 184-189, 2004.

16. Duxbury MS, Ito $H$, Zinner MJ, Ashley SW and Whang EE: Inhibition of SRC tyrosine kinase impairs inherent and acquired gemcitabine resistance in human pancreatic adenocarcinoma cells. Clin Cancer Res 10: 2307-2318, 2004. 
17. Arrigo AP: Hsp27: novel regulator of intracellular redox state. IUBMB Life 52: 303-307, 2001.

18. Concannon CG, Gorman AM and Samali A: On the role of Hsp27 in regulating apoptosis. Apoptosis 8: 61-70, 2003.

19. Garrido C, Bruey JM, Fromentin A, Hammann A, Arrigo AP and Solary E: HSP27 inhibits cytochrome c-dependent activation of procaspase-9. FASEB J 13: 2061-2070, 1999.

20. Samali A, Robertson JD, Peterson E, et al: Hsp27 protects mitochondria of thermotolerant cells against apoptotic stimuli. Cell Stress Chaperones 6: 49-58, 2001.

21. Hansen RK, Parra I, Lemieux P, Oesterreich S, Hilsenbeck SG and Fuqua SA: Hsp27 overexpression inhibits doxorubicininduced apoptosis in human breast cancer cells. Breast Cancer Res Treat 56: 187-196, 1999.

22. Gibbons NB, Watson RW, Coffey RN, Brady HP and Fitzpatrick JM: Heat-shock proteins inhibit induction of prostate cancer cell apoptosis. Prostate 45: 58-65, 2000.

23. Urbani A, Poland J, Bernardini S, et al: A proteomic investigation into etoposide chemo-resistance of neuroblastoma cell lines. Proteomics 5: 796-804, 2005.

24 Masashi T, Eiki N, Hirotoshi H, et al: Heat shock protein 27 is involved in acquisition of 5-fluorouracil resistance in human colon cancer. Proceedings of 67th annual meeting of the Japanese Cancer Association 425, 2005.

25. Herrera JE, Savkou R and Olson MO: The ribonuclease activity of nucleolar protein B23. Nucleic Acids Res 23: 3974-3979, 1995.

26. Okuwaki M, Matsumoto K, Tsujimoto M and Nagata K: Function of nucleophosmin/B23, a nucleolar acidic protein, as a histone chaperone. FEBS Lett 506: 272-276, 2001.
27. Li J, Zhang X, Sejas DP and Pang O: Negative regulation of p53 by nucleophosmin antagonizes stress-induced apoptosis in human normal and malignant hematopoietic cells. Leuk Res 29: $1415-1423,2005$

28. Liu WH, Hsu CY and Yung BY: Nucleophosmin/B23 regulates the susceptibility of human leukemia HL-60 cells to sodium butyrate-induced apoptosis and inhibition of telomerase activity. Int J Cancer 81: 923-929, 1999.

29. Hsu CY and Yung BY: Over-expression of nucleophosmin/B23 decreases the susceptibility of human leukemia HL-60 cells to retinoic acid-induced differentiation and apoptosis. Int J Cancer 88: 392-400, 2000.

30. Gao H, Jin S, Song Y, et al: B23 regulates GADD45a nuclear translocation and contributes to GADD45a-induced cell cycle G2-M arrest. J Biol Chem 280: 10988-11096, 2005.

31. Friess H, Lu Z, Graber HU, et al: bax, but not bcl-2, influences the prognosis of human pancreatic cancer. Gut 43: 414-421, 1998.

32. Chang GC, Hsu SL, Tsai JR, Wu WJ, Chen CY and Sheu GT: Extracellular signal-regulated kinase activation and Bcl-2 downregulation mediate apoptosis after gemcitabine treatment partly via a p53-independent pathway. Eur J Pharmacol 19: 169-183, 2004.

33. Xu Z, Friess H, Solioz M, Aebi S, Korc M, Kleeff J and Buchler MW: Bcl-x(L) antisense oligonucleotides induce apoptosis and increase sensitivity of pancreatic cancer cells to gemcitabine. Int J Cancer 94: 268-274, 2001. 